DR. JESSE MITCHEM (Orcid ID : oooo-0oo1-9833-0320)

DR. THOMAS R. KATONA (Orcid ID : oooo-0001-9949-7237)

MS. ELIZABETH A. S. MOSER (Orcid ID : 0000-0002-2673-3662)

Article type : Original Article

\begin{tabular}{|l|l|}
\hline Title & $\begin{array}{l}\text { Does the presence of an occlusal indicator product affect } \\
\text { the contact forces between full dentitions? }\end{array}$ \\
\hline Short title & Occlusal contact forces \\
\hline Article category & Original article \\
\hline Name & Jesse A. Mitchem \\
& Thomas R. Katona \\
& Elizabeth A. S. Moser \\
\hline Affiliations & Jesse A. Mitchem: \\
& Department of Orthodontics and Oral Facial Genetics \\
& School of Dentistry \\
& Indiana University \\
& Indianapolis, USA \\
& \\
& Thomas R. Katona: \\
& Department of Orthodontics and Oral Facial Genetics \\
& School of Dentistry \\
& Indiana University \\
& Indianapolis, USA \\
& Elizabeth A. S. Moser: \\
& Department of Biostatistics \\
& School of Medicine \\
& Indiana University \\
& Indianapolis, USA \\
\hline Corresponding author & Indiana University School of Dentistry \\
& IUPUI \\
& 1121 W. Michigan St. \\
Indianapolis, IN 46202, USA \\
tkatona@iu.edu
\end{tabular}

This is the author's manuscript of the article published in final edited form as:

Mitchem, J. A., Katona, T. R. and Moser, E. A. S. (), Does the presence of an occlusal indicator product affect the contact forces between full dentitions?. J Oral Rehabil. Accepted Author Manuscript. http://dx.doi.org/10.1111/joor.12543 


\section{Does the presence of an occlusal indicator product affect the contact forces between full dentitions?}

SUMMARY: Studies have explored occlusal marking interpretation, repeatability and accuracy. But, when an occlusion detection product is interposed between teeth, direct toothtooth occlusal contact relationships are replaced by tooth-material-tooth structures. Thus, the marks cannot reflect the original contacts. This has been shown for single tooth pair contacts. The purpose of this laboratory study was to similarly examine full dentitions. A dentiform was set into Class I centric occlusion with the mandible supported by a load cell. The maxillary arch was guided by precision slides. As the weighted $(\sim 52 \mathrm{~N})$ upper assembly was lowered onto and raised off the mandibular arch, the loads on the mandible were measured. With and without (control) occlusal marking material, the steps were: (cleaning - control 1 material 1) ... (cleaning - control 6 - material 6). The 6 materials were: Accufilm I and II, Rudischhauser Thick and Thin, Hanel Articulating Silk, and T-Scan. Then, the 6 sets of (cleaning - control - material) measurements were repeated with the mandibular assembly shifted, in turn, by $0.1 \mathrm{~mm}$ in the Anterior, Posterior, Right and Left directions. The 5 (Centric and four $0.1 \mathrm{~mm}$ shifted) occlusal relationships produced grossly different toothtooth (control) load profiles. And, in general, these controls were affected, in different ways, by the marking products. Among the 5 conventional products, the Rudischhausers fared the worst and the electronic T-Scan was an extreme outlier. Thus, in general, popular occlusal detection products alter the occlusal contact forces, and therefore, their markings cannot characterize the actual occlusion.

KEYWORDS: articulating paper, dental occlusion, occlusal equilibration, occlusal force, TScan, bite force

\section{Introduction}

When an occlusal contact marking product is interposed between teeth, the recorded markings reflect a tooth-product-tooth, not the actual tooth-tooth, configuration (1). As these products are universal dental armamentaria in many laboratory and clinical procedures (2-4), this presents potentially serious and widespread ramifications. There is considerable literature

This article is protected by copyright. All rights reserved. 
about these products' efficacy and the interpretations of their markings (5-7), and some believe that there are too many concerns to use them as diagnostic tools $(3,8,9)$.

Reproducibility of visual occlusal detection methods is unreliable $(7,9,10)$ even when identical occlusal marking mediums are used on identical occlusal contacts $(8,9)$. Conflicting results have been published about the relationships between contact mark size and force magnitude $(5-7,11)$ and between mark size and product thickness $(6,9,12-14)$. Another study demonstrated that thick products elicit a proprioceptive response, comparable to occluding on a cotton roll, which can alter the direction of the mandible on closing, while thinner products tend to allow the mandible and its musculature to act similarly to a natural bite (15).

Furthermore, engineering analyses suggest a link between the presence of these products and changes in the occlusal contact forces $(16,17)$. Rather than relying on visual evidence, a study demonstrated changes in loads on single pairs of contacting teeth with, and without, the presence of marking indicators (1). The purpose of this project was to measure load alterations caused by six common occlusal detection products on a full arch of teeth.

\section{Materials and methods}

A full dentiform (REF 600 210, 3M Unitek, Monrovia, CA, USA) was set into its asmanufactured centric occlusion, Figs 1a and b. The mandibular arch was supported by a load cell (Gamma Transducer, SI-65-5, ATI Industrial Automation, Apex, NC, USA) that measured forces and moments $0-65 \pm 0.2 \mathrm{~N}$ and $0-5000 \pm 0.9 \mathrm{~N}-\mathrm{mm}$, respectively. The maxillary arch was carried by a pair of vertically mounted precision slides (Mini-Guide, Double Carriage, Model \#SEBS 9BUU2-275, Nippon Bearing Co, Ojiya, Japan). The entire assembly was bolted onto a mechanical testing machine (MTS Bionix 858, MTS Corporation, Minneapolis, MN, USA).

The MTS machine was used to manually lower the maxillary assembly $(\sim 52 \mathrm{~N})$ onto the mandibular arch until a slight slack developed in the supporting chain (Figs 1a and b), thus ensuring that the arches were fully seated. That position of the hydraulic MTS actuator was set as its $0 \mathrm{~mm}$ point. The arches were then manually separated with the MTS, and then with or without (the controls) the products, the programmed ramp cycle ( $2 \mathrm{~mm}$ amplitude at $0.2 \mathrm{~Hz}$ ) was run for 3 cycles. The load cell readings during the second cycle were used as data. The loads on the mandible (Fig. 2) were recorded by a dedicated laptop computer at a

This article is protected by copyright. All rights reserved. 
rate of 100/sec using the load cell-packaged NI-DAQmx software (National Instruments Corporation, Austin, TX, USA).

$\mathrm{F}_{\text {lateral, }}$ the magnitude of the force component that acts within the occlusal plane was calculated with the Pythagorean Theorem,

$$
F_{\text {lateral }}=\sqrt{{F_{x}^{2}}^{2}+F_{y}^{2}}
$$

where $\mathrm{F}_{\mathrm{x}}$ and $\mathrm{F}_{\mathrm{y}}$ are the right-left and the anterior-posterior force components, respectively, measured by the load cell (Fig. 2). $F_{\text {lateral }}$ 's direction, $\theta$, measured counterclockwise from the positive $\mathrm{x}$-axis, is equal to

$$
\theta=\operatorname{ATAN}\left(\mathrm{F}_{\mathrm{y}} / \mathrm{F}_{\mathrm{x}}\right)
$$

Also measured by the load cell, $\mathrm{F}_{\mathrm{z}}$, is the occlusal force that is applied as the upper member is lowered onto the mandibular arch, and $\mathrm{M}_{\mathrm{x}}, \mathrm{M}_{\mathrm{y}}$ and $\mathrm{M}_{\mathrm{z}}$, the moment vector components indicated by the white arrowheads in Fig. 2. The directions of the M-induced rotational tendencies of the mandible are given by the Right-Hand-Rule (18). For example, a positive $M_{x}$ would tend to "open" rotate the mandible, while a negative $M_{x}$ would tend to "close" it. The magnitude of the moment vector is,

$$
M=\sqrt{M_{x}^{2}+M_{y}^{2}+M_{z}^{2}} .
$$

Tests of the 6 products (Table 1) were conducted in the following sequence: (cleaning - control 1 - material 1) - (cleaning - control 2 - material 2) - (cleaning - control 3 material 3) $-(\ldots-\ldots-$ material 6$)$. With this protocol, each material measurement had its own control. The 6 materials, tested in random order, were: Accufilm I (Af1) and II (Af2), Rudischhauser Thick (RThick) and Thin (RThin), Hanel Articulating Silk (Silk), and T-Scan (TScan). Then, the 6 sets of (cleaning - control - material) measurements were repeated, in random order each time, with the mandibular assembly shifted, in turn, by $0.1 \mathrm{~mm}$ in the Anterior, Posterior, Left and Right directions, Fig. 1c.

This article is protected by copyright. All rights reserved. 
The cleaning at each measurement consisted of thoroughly removing any traces of the previous product's markings with a 95\% ethanol alcohol solution on a two-inch by two-inch cotton gauze (generic), dried with cotton gauze and compressed air. If the product was not available in a horseshoe shape, 2 pieces were laid on the lower dentition.

\section{Statistical Methods \& Sample Size}

Summary statistics (mean, range and standard deviation) of the measured loads were calculated for each of the products. Due to non-normality and the presence of interactions, one-way nonparametric tests were used for all comparisons. A Wilcoxon rank-sum test was used to compare the materials and their controls for $\mathrm{F}_{\text {lateral }}, \theta, \mathrm{Mx}, \mathrm{My}, \mathrm{Mz}$ and $\mathrm{M}$. A one-way ANOVA of the ranks-rank-transformed data was used to compare the effects of the (Anterior, Posterior, Left and Right) shifts on $F_{\text {lateral }}$ and $\theta$ of the control measurements. A 5\% significance level was used for all tests without controlling for multiple comparisons and with the understanding that this may have led to some false discovery. Reliability was assessed by the comparisons of these 6 controls within each of the 5 occlusal relationships, i.e., the left column in Fig. 3b. Reliability was also tested by continuously recording a Centric control through 11 complete cycles and calculating intraclass correlation coefficients.

For the "overall" ( $\mathrm{F}_{\text {lateral }}, \theta, \mathrm{Mx}, \mathrm{My}, \mathrm{Mz}$, and $\mathrm{M}$ for each of the products) groups, there were 90 observations, ( $9 \mathrm{Fz}$ values $\mathrm{x} 2$ directions $\mathrm{x} 5$ shifts $=90)$. For the data broken down by the direction of the shift, we had 18 observations ( $9 \mathrm{Fz}$ values $\mathrm{x} 2$ directions $=18$ ).

\section{RESULTS}

Six products were tested in 5 occlusal relationships, for a total of 30 combinations, Table 2. In addition, each combination had its own control. The measurements are presented in the form of $\mathrm{F}_{\text {lateral }}$ and its direction, $\theta$, Figs $3 \mathrm{~b}$ and $3 \mathrm{c}$, respectively. The right columns in Figs $3 \mathrm{~b}$ and $3 \mathrm{c}$ contain the 30 position/material measurements-(\#1-\#30), while the left columns show their corresponding controls $(\# 1 \mathrm{C} \# 30 \mathrm{C})$. Although the materials were tested in different random sequences within each of the 5 occlusal relationships, they are consistently presented in the Af1, Af2, RThin, RThick, Silk and T-Scan order. The intraclass correlation coefficients were 0.94 and 0.72 for $F_{\text {lateral }}$ and $\theta$, respectively.

Statistical results are summarized in Fig. 4. The primary focus, the comparison of loads measured with and without (control) the presence of a product, is shown in Fig. 4a. Figure $4 \mathrm{~b}$ highlights the occlusion vs. disclusion differences. The p-values in the Overall

This article is protected by copyright. All rights reserved. 
columns of Fig. 4a are shown in Table 2. Although Mx, My, Mz and M are not presented in detail as in Fig. 3, they are included in Fig. 4 and Table 2.

\section{DISCUSSION}

Primary emphasis is on $\mathrm{F}_{\text {lateral }}$ (the force component in the occlusal plane) and its direction, $\theta$, both calculated from the measured Fx and Fy force components, Fig. 2. Based solely on $\mathrm{F}_{\text {lateral }}$ and/or $\theta$, Fig. 4a, it can be concluded that these products alter the loading experienced by the arches. The moment measurements (Fig. 4a) and the Overall values (Fig. 4a and Table 2) renly reinforce this conclusion. The least emphasis should be placed on $\mathrm{Mz}$ because generally it is small.

All 4 (Anterior, Posterior, Left and Right) $0.1 \mathrm{~mm}$ shifts of the mandibular arch produced significant changes in control $\mathrm{F}_{\text {lateral }}$ and $\theta$ when compared to Centric and to each other, all with p-values $<0.0001$. (Compare the sets of curves in the left columns of Figs $3 b$ and 3c.) Thus, the 5 occlusal arrangements can be considered as distinctly different occlusal relationships, thereby satisfying a requirement for the statistical analyses. It is also noteworthy that a $0.1 \mathrm{~mm}$ mandibular shift is sufficient to produce such changes in the occlusal contact forces.

It was found that the 6 control $F_{\text {lateral }}$ and $\theta$ measurements within the Anterior, Posterior, Left and Right offset groups were not statistically different, but those within the Centric relationship were different from each other. This possibility was anticipated, and it is precisely the reason for the repeated (cleaning - control - material) sequence in the experimental design. The need for the individual controls was based on the risk that the cleanings could ever-so-slightly disturb the apparatus. The Centric relationship is the most stable position and so it seems that the slightest perturbations away from it induce the greatest relative changes.

Product performance assessment was based on the difference between the product's measurements and its corresponding control measurements. As an example, for $\theta$, the difference was defined as the quantity, $\theta_{\text {product }}-\theta_{\text {control }}$. This calculation was performed for values of $\theta$ that were linearly interpolated to correspond to $F_{z}=5,10,15, \ldots 45 \mathrm{~N}$. (These 9 data points are illustrated in Fig. 3a and in the top right panel of Fig. 3b.) The smaller the deviation from the respective control, the better the performance.

Expressed in terms of p-values relative to 0.05, Af1, Af2 and Silk performed better than RThin, RThick and T-Scan, Fig. 4a and Table 2. (Of the same 6 materials, Silk fared the 
best in a study of single pair tooth contact (1)). T-Scan is a thick material, Table 1, and perhaps more importantly, it is stiff. Thus, it acts to "bridge" the cusp tips, effectively converting the bite into a flat-plane occlusion. This is entirely consistent with its relatively small $\mathrm{F}_{\text {lateral }}$ magnitudes, Fig. $3 \mathrm{~b}$.

The causes of discrepancies between the other materials and their controls, and between each material's occlusion and disclusion (Fig. 4b), are more complicated. It appears that the products act to cushion the contacts, thus the initial $\left(F_{z}=5 N\right)$ control $F_{\text {lateral }}$ magnitudes are consistently higher than those with the products, Fig. 3b. On disclusion, the path in the material is already crushed or ploughed, hence there is less discrepancy between control and material. The occlusion/disclusion differences also suggest a link to friction (19) and because these differences are much less pronounced with Af1, Af2 and Silk than with RThin and RThick, it may be due to the lubricating quality of their marking ink. (This is not to suggest that a good lubricant is better or worse than a poor lubricant.)

It is interesting to note that Af1 is half as thick as Af2, yet Af1's performance is only marginally better, Fig. 4a. In turn, Silk is more than twice as thick as Af2, yet their performances are similar. It therefore appears that the relatively good performances of Af1, Af 2 and Silk may be attributable to serendipitous combinations of material thickness, stiffness and lubricative property.

The evidence demonstrates that RThick, RThin and TScan cannot replicate actual tooth-tooth contacts (Fig. 4a) and that Af1, Af2 and Silk exhibit deficiencies in Centric occlusion. Thus, it appears that long-standing controversies about occlusal mark interpretations are focused on artefactual observations.

These products are used in a wide range of applications, ranging from hinge-mounted models, ankylosed teeth and implant supported bridges, to periodontally compromised teeth. Somewhere within that broad stiffness spectrum are healthy teeth, full dentures and our apparatus. Clearly, extreme caution should be exercised in generalizing these study results, but it is not unreasonable to suggest that the deficiency phenomena described herein are inherent in all applications of these materials. More research is needed to better define the details of those inadequacies.

\section{DISCLOSURES}

The authors have no conflicts of interest, ethics approval was not required, and only internal support was utilized. We thank Mr. George Eckert for his assistance with the statistics.

This article is protected by copyright. All rights reserved. 


\section{REFERENCES}

1. Helms RB, Katona TR, Eckert GJ. Do occlusal contact detection products alter the occlusion? J Oral Rehabil. 2012;39:357-363.

2. Aubrey RB. Occlusal objectives in orthodontic treatment. Am J Orthod. 1978;74:162175.

3. Baba K, Tsukiyama Y, Clark GT. Reliability, validity, and utility of various occlusal measurement methods and techniques. J Prosthet Dent. 2000;83:83-89.

4. Kimmel SS. Rationale and technique for achieving occlusal harmony. N Y State Dent J. 2009;75:39-43.

5. Carey JP, Craig M, Kerstein RB, Radke J. Determining a relationship between applied occlusal load and articulating paper mark area. Open Dent J. 2007;1:1-7.

6. Saad MN, Weiner G, Ehrenberg D, Weiner S. Effects of load and indicator type upon occlusal contact markings. J Biomed Mater Res B Appl Biomater. 2008;85:18-22.

7. Kerstein RB, Radke J. Clinician accuracy when subjectively interpreting articulating paper markings. Cranio. 2014;32:13-23.

8. Gazit E, Fitzig S, Lieberman MA. Reproducibility of occlusal marking techniques. J Prosthet Dent. 1986;55:505-509.

9. Millstein P, Maya A. An evaluation of occlusal contact marking indicators. A descriptive quantitative method. J Am Dent Assoc. 2001;132:1280-1286; quiz 1319.

10. Halperin GC, Halperin AR, Norling BK. Thickness, strength, and plastic deformation of occlusal registration strips. J Prosthet Dent. 1982;48:575-578.

11. Komiyama O, Obara R, Iida T, Asano T, Masuda M, Uchida T et al. Comparison of direct and indirect occlusal contact examinations with different clenching intensities. $\mathbf{J}$ Oral Rehabil. 2015;42:185-191.

12. Schelb E, Kaiser DA, Brukl CE. Thickness and marking characteristics of occlusal registration strips. J Prosthet Dent. 1985;54:122-126.

13. Toledo MF, Joias RP, Marques-Iasi YS, Neves AC, Rode Sde M. Thickness and marking quality of different occlusal contact registration strips. J Appl Oral Sci. 2014;22:516-521.

14. Brizuela-Velasco A, Alvarez-Arenal A, Ellakuria-Echevarria J, del Rio-Highsmith J, Santamaria-Arrieta G, Martin-Blanco N. Influence of Articulating Paper Thickness on Occlusal Contacts Registration: A Preliminary Report. Int J Prosthodont. 2015;28:360-362.

This article is protected by copyright. All rights reserved. 
15. Forrester SE, Presswood RG, Toy AC, Pain MT. Occlusal measurement method can affect SEMG activity during occlusion. J Oral Rehabil. 2011;38:655-660.

16. Katona TR. The effects of cusp and jaw morphology on the forces on teeth and the temporomandibular joint. J Oral Rehabil. 1989;16:211-219.

17. Katona TR. An engineering analysis of dental occlusion principles. Am J Orthod Dentofacial Orthop. 2009;135:696.e691-698; discussion 696-697.

18. Beer FP, Johnston ER, Mazurek DF. Vector Mechanics for Engineers - Statics, 11th ed. New York: McGraw Hill; 2016.

19. McCrea ES, Katona TR, Eckert GJ. The effects of salivas on occlusal forces. J Oral Rehabil. 2015;42:348-354.

20. Barzilay I. Articulation paper and other occlusal marking devices revisited. Dentist's Guide / CDE. 1996:23-26.

Table 1. Product information.

\begin{tabular}{|c|c|c|c|c|}
\hline \multicolumn{2}{|l|}{ Product } & \multirow{2}{*}{$\begin{array}{c}\text { Thickness } \\
(\mu \mathrm{m})(1) \\
19\end{array}$} & \multirow{2}{*}{$\begin{array}{l}\text { Manufacturer } \\
\text { Parkell, Inc., Edgewood, } \\
\text { NY, USA }\end{array}$} & \multirow{2}{*}{$\begin{array}{r}\text { Type } \\
{ }^{\mathrm{a}} \text { Mylar }\end{array}$} \\
\hline Accufilm I & (Af1) & & & \\
\hline Accufilm II & $(\mathrm{Af} 2)$ & 38 & \multirow{3}{*}{$\begin{array}{l}\text { Dental Articulating Paper, } \\
\text { San Diego, CA, USA }\end{array}$} & \multirow{3}{*}{${ }^{\mathrm{b}}$ Carbon paper } \\
\hline $\begin{array}{l}\text { Rudischhauser } \\
\text { Thick }\end{array}$ & (RThick) & 80 & & \\
\hline $\begin{array}{l}\text { Rudischhauser } \\
\text { Thin }\end{array}$ & (RThin) & 70 & & \\
\hline $\begin{array}{l}\text { Hanel } \\
\text { Articulating Silk }\end{array}$ & (Silk) & 85 & $\begin{array}{l}\text { Whaledent, Inc., Cuyahoga } \\
\text { Falls, OH, USA }\end{array}$ & ${ }^{\mathrm{c}}$ Natural silk \\
\hline T-Scan & (TScan) & 98 & $\begin{array}{l}\text { Tekscan, Inc., South } \\
\text { Boston, MA, USA }\end{array}$ & $\begin{array}{l}{ }^{\mathrm{d}} \text { Electronic, } \\
\text { Polyester }\end{array}$ \\
\hline \multicolumn{5}{|c|}{$\begin{array}{l}\text { b GE RUDISCHHAUSER Trademark Information (http://www.trademarkia.com/ge- } \\
\text { rudischhauser-72111169.html) }\end{array}$} \\
\hline \multicolumn{5}{|c|}{$\begin{array}{l}{ }^{c} \text { HANEL Occlusion World Catalogue } \\
\text { (https://www.coltene.com/fileadmin/Data/EN/Products/Laboratory/Occlusion_Control/Ha } \\
\text { nel_Articulating_Silk/60013731_04-13_EN_Hanel.pdf, Page 10) }\end{array}$} \\
\hline
\end{tabular}

This article is protected by copyright. All rights reserved. 
Table 2. p-values for differences between each material and its control. Statistically significant differences $(\mathrm{p}<0.05)$ are bolded.

\begin{tabular}{|l|c|c|c|c|c|c|}
\hline & Af1 & Af2 & RThick & RThin & Silk & TScan \\
\hline $\mathrm{F}_{\text {lat }}$ & 0.8334 & 0.6919 & $<.0001$ & $<.0001$ & 0.0848 & $<.0001$ \\
\hline$\theta$ & 0.7935 & 0.6877 & 0.1631 & 0.0874 & 0.3215 & $<.0001$ \\
\hline $\mathrm{Mx}$ & 0.4492 & 0.5604 & $\mathbf{0 . 0 0 0 3}$ & $\mathbf{0 . 0 0 0 2}$ & 0.1505 & $<.0001$ \\
\hline $\mathrm{My}$ & 0.2507 & 0.2460 & $\mathbf{0 . 0 0 7 3}$ & $\mathbf{0 . 0 1 8 6}$ & $\mathbf{0 . 0 3 1 3}$ & 0.1896 \\
\hline $\mathrm{Mz}$ & 0.8469 & 0.1867 & $\mathbf{0 . 0 3 1 6}$ & 0.4289 & 0.0611 & 0.8023 \\
\hline $\mathrm{M}$ & 0.2892 & 0.5263 & $\mathbf{0 . 0 0 0 1}$ & $<.0001$ & 0.0673 & $<.0001$ \\
\hline
\end{tabular}

\section{FIGURE LEGENDS}

Fig. 1. Testing apparatus. (a) Schematic of testing apparatus. (b) This picture shows T-Scan being tested. (c) The $0.1 \mathrm{~mm}$ mandibular shifts were controlled by 0.1 and $0.2 \mathrm{~mm}$ shims (Feeler Stock, Starrett Company, Athol, MA) positioned between the load cell's aluminum base and a fixed carpenter square. Centric, Left and Posterior shifts are illustrated.

Fig. 2. All 6 load (Fx, Fy, Fz, Mx, My and Mz) components on the mandible were simultaneously measured by the load cell. The directions of moments, indicated by the openhead arrows, is consistent with the right-hand-rule. The occlusal plane force component, $F_{\text {lateral }}$, and its direction, $\theta$, are derived from Fx and Fy. $\theta$ is measured counterclockwise from the $+\mathrm{x}$-axis. In this illustration, $\theta \approx 210^{\circ}$.

Fig. 3. (a) The graphing details are explained with the results for Af1 in Centric occlusion. The horizontal axis is Fz. The vertical axis is $\mathrm{F}_{\text {lateral }}$. The $\mathrm{F}_{\text {lateral }} \mathrm{s}$ (circle symbols) are linearly interpolated to $\mathrm{Fz}=5,10,15,20,25,30,35,40$ and $45 \mathrm{~N}$ in the occluding phase (solid line) and in the discluding phase (dashed line). (b) The right column contains $F_{\text {lateral }}$ for the Material measurements (\#1 - \#30 in Table 1). The left column shows the associated controls (\#1C $\# 30 \mathrm{C}$ ). Figure $3 \mathrm{a}$ is highlighted in the top right cell. (c) Same as (b) except for $\theta$.

Fig. 4. Summaries of statistical results. (a) Symbols indicate significant $(\mathrm{p}<0.05)$ differences between the material and its control during occlusion $(\bullet)$ and disclusion $(\boldsymbol{\bullet})$. The $\boldsymbol{\Delta}$ indicate significant differences when direction (occluding and discluding) and shift (Centric, Anterior, Posterior, Left and Right) are all lumped together. (b) Significant $(\mathrm{p}<0.05)$ differences between occlusion and disclusion for the material ( $\bullet$ ) and for its control $(\bullet)$.

This article is protected by copyright. All rights reserved. 


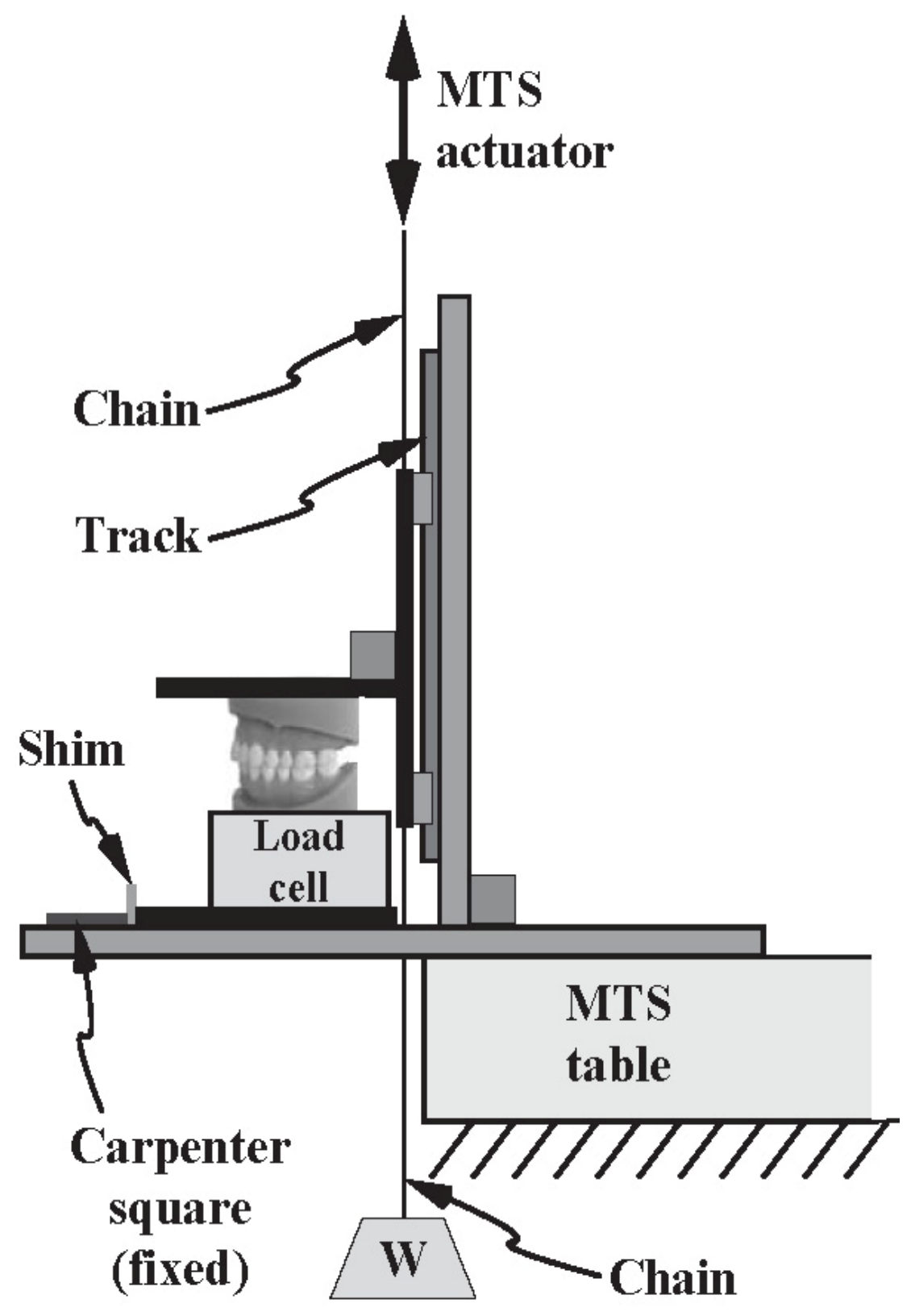

This article is protected by copyright. All rights reserved. 


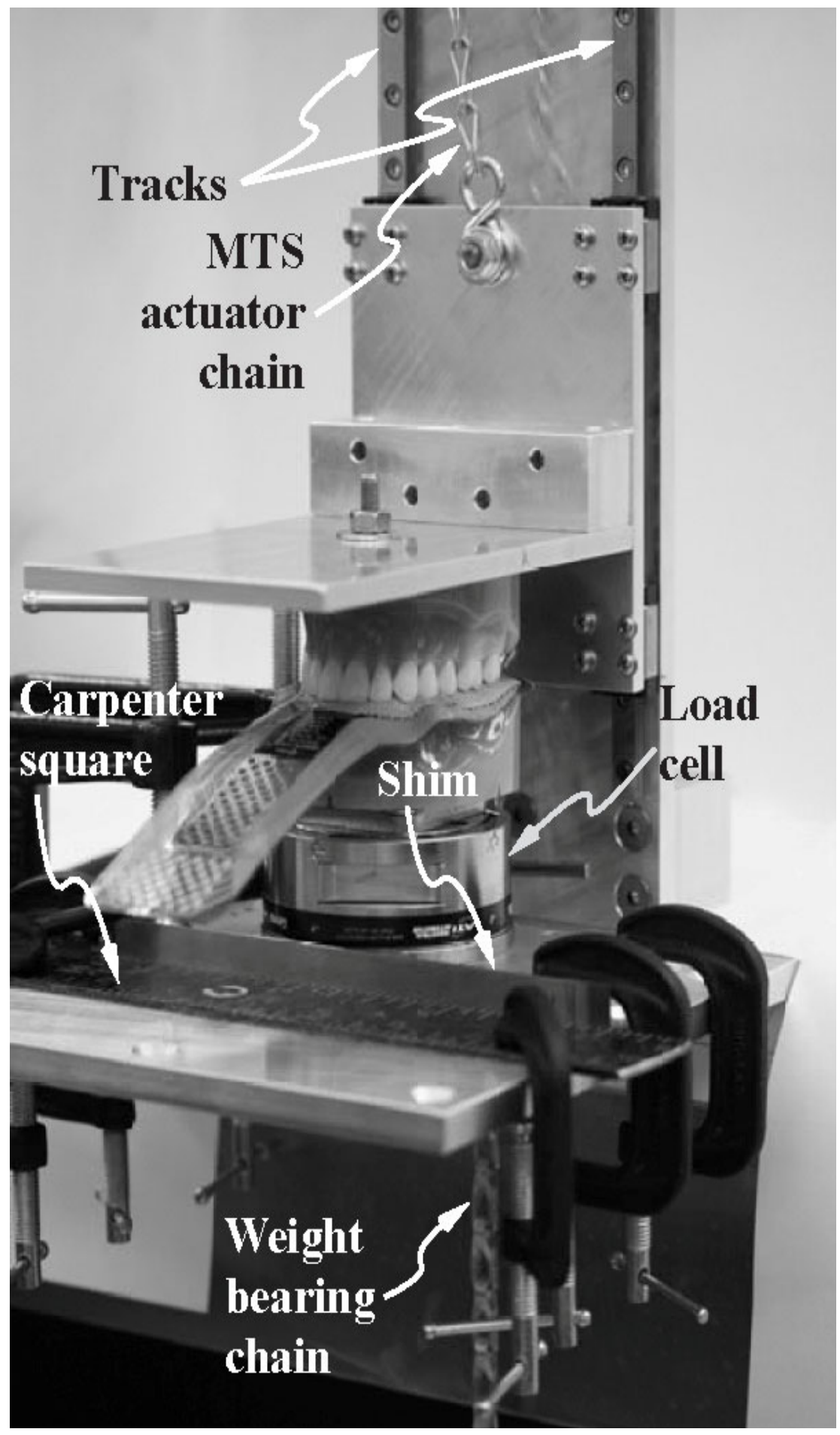

This article is protected by copyright. All rights reserved. 

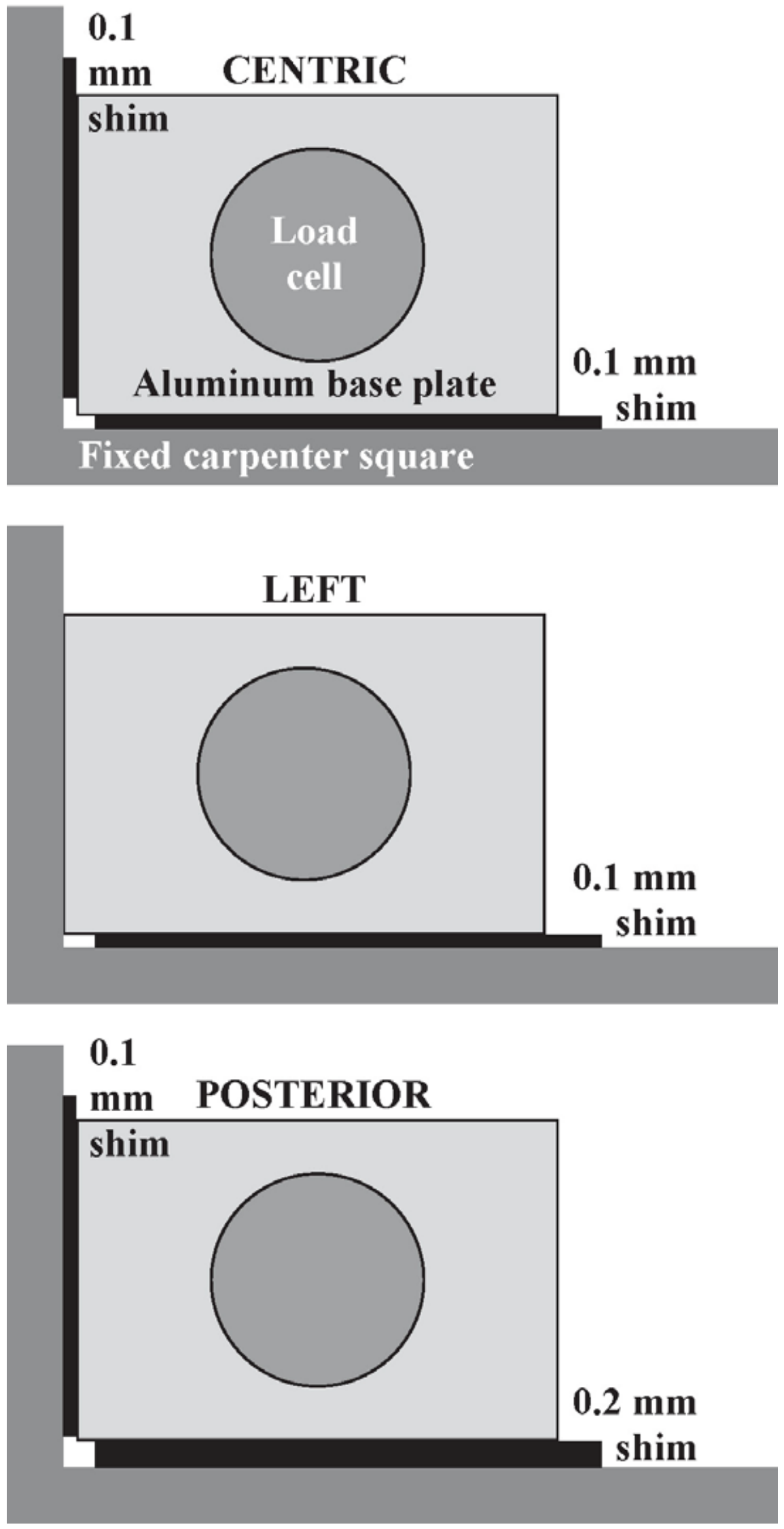

This article is protected by copyright. All rights reserved. 


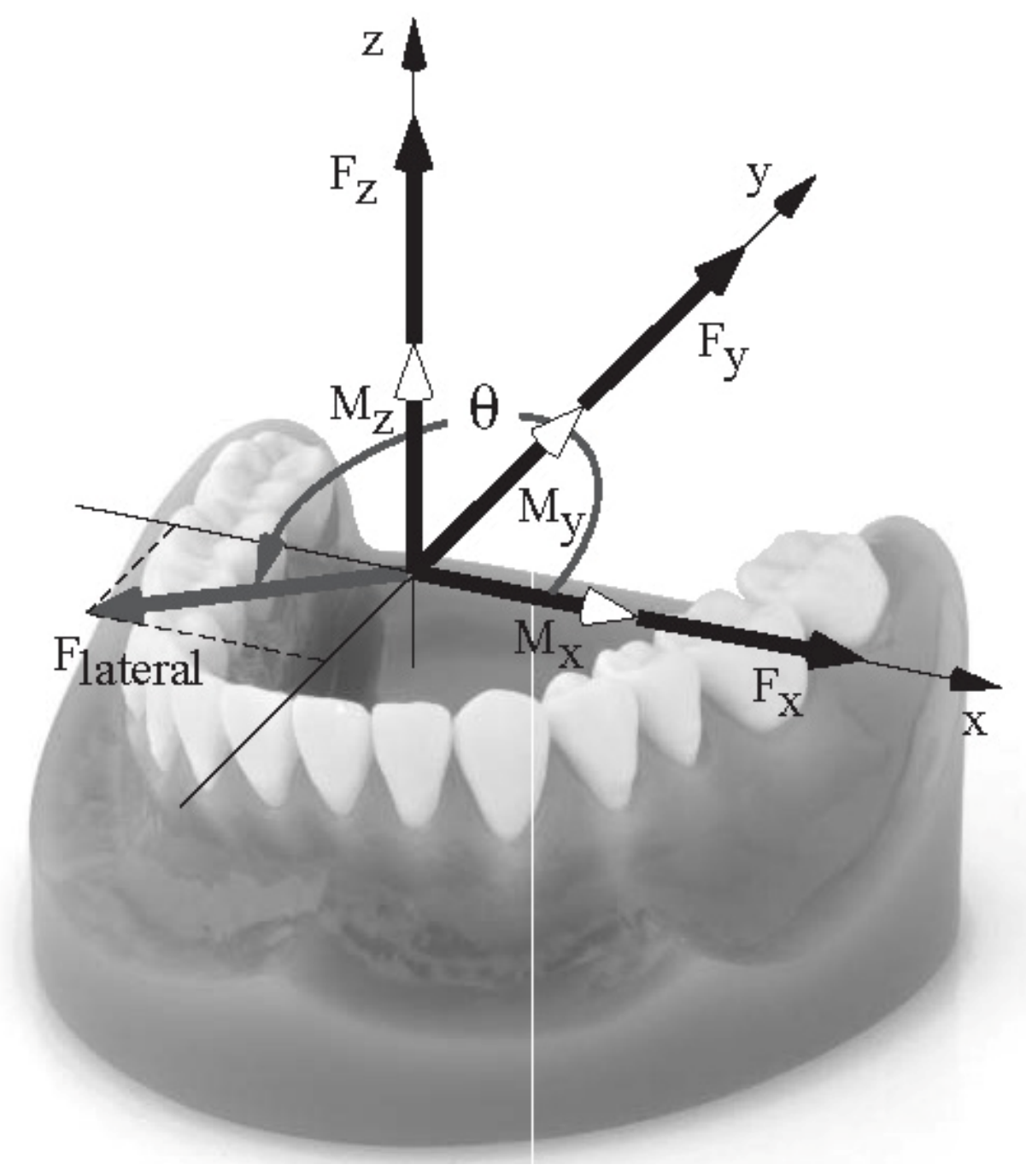

This article is protected by copyright. All rights reserved. 


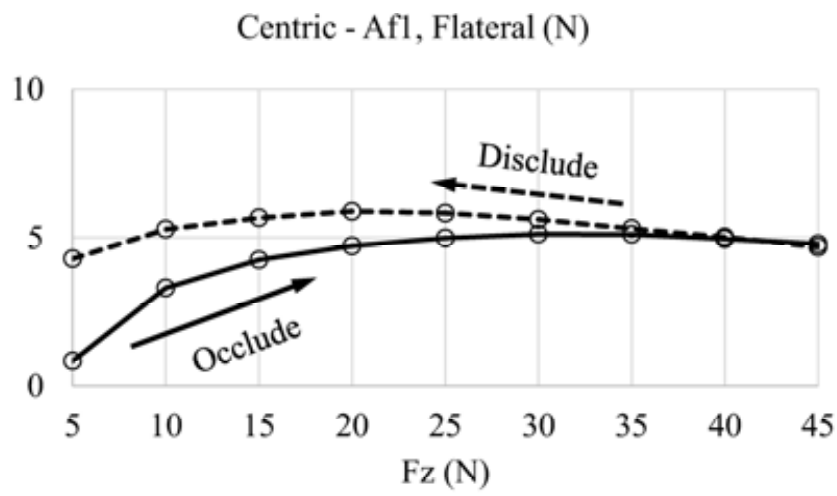

This article is protected by copyright. All rights reserved. 


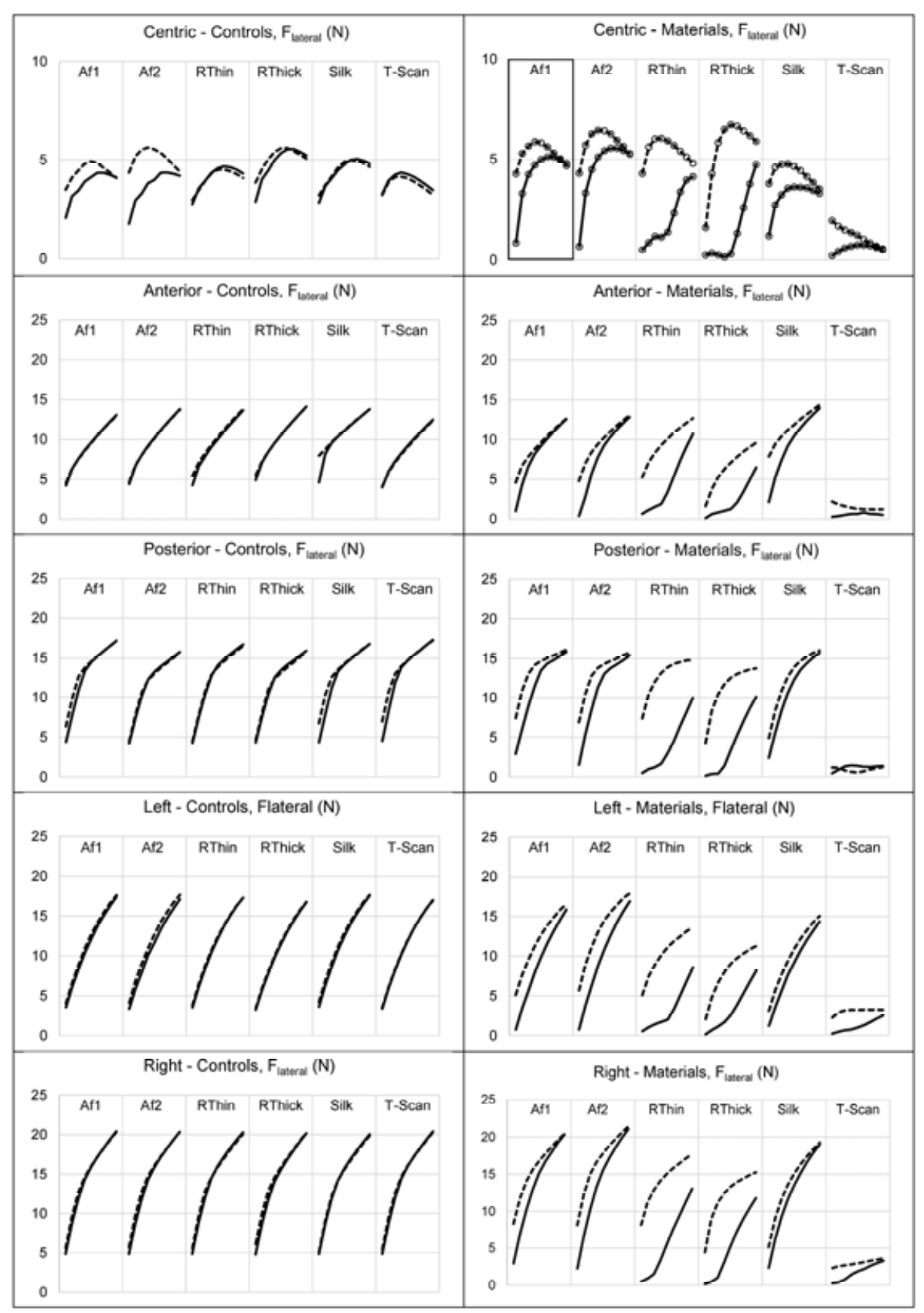

This article is protected by copyright. All rights reserved. 


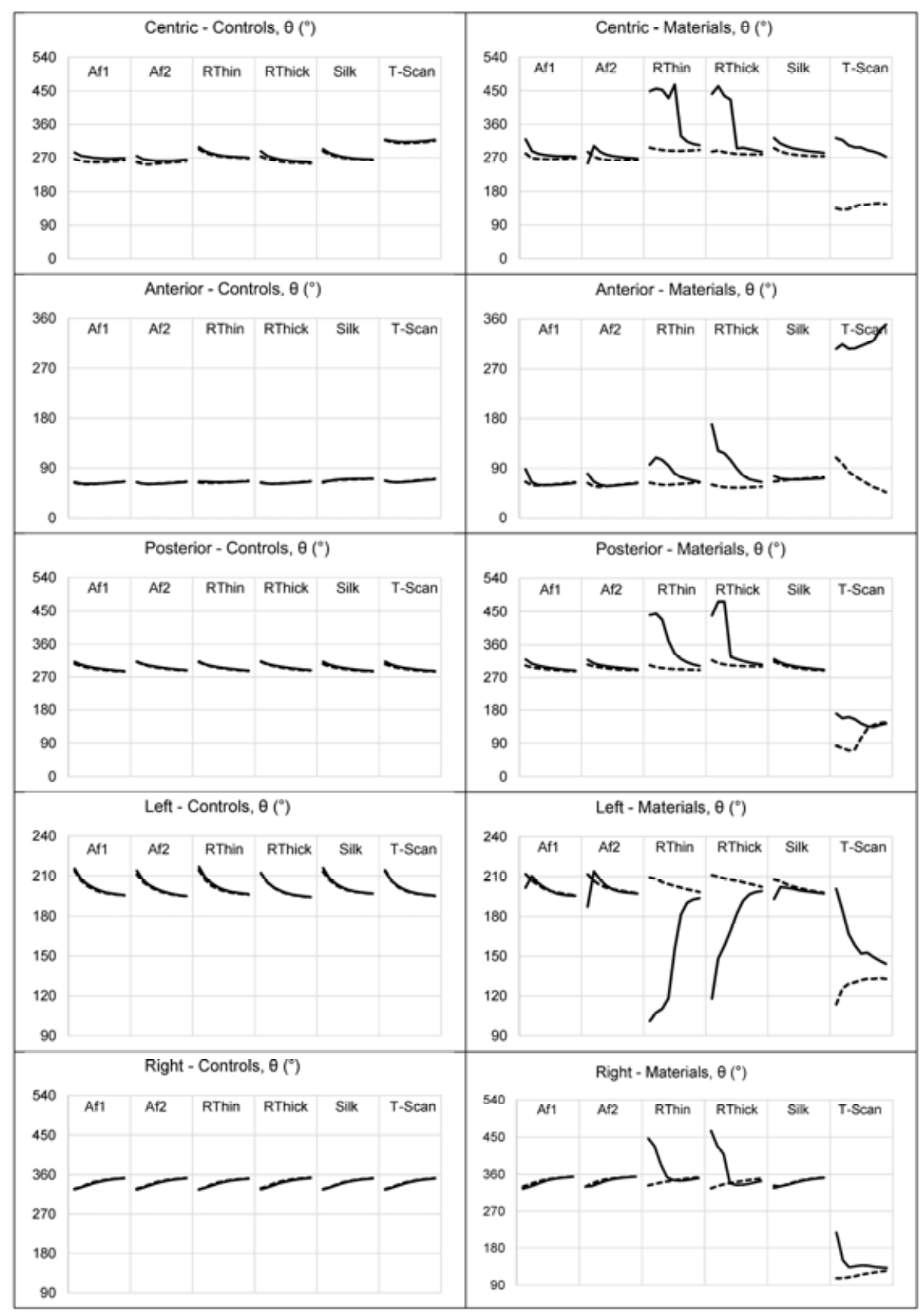

This article is protected by copyright. All rights reserved. 


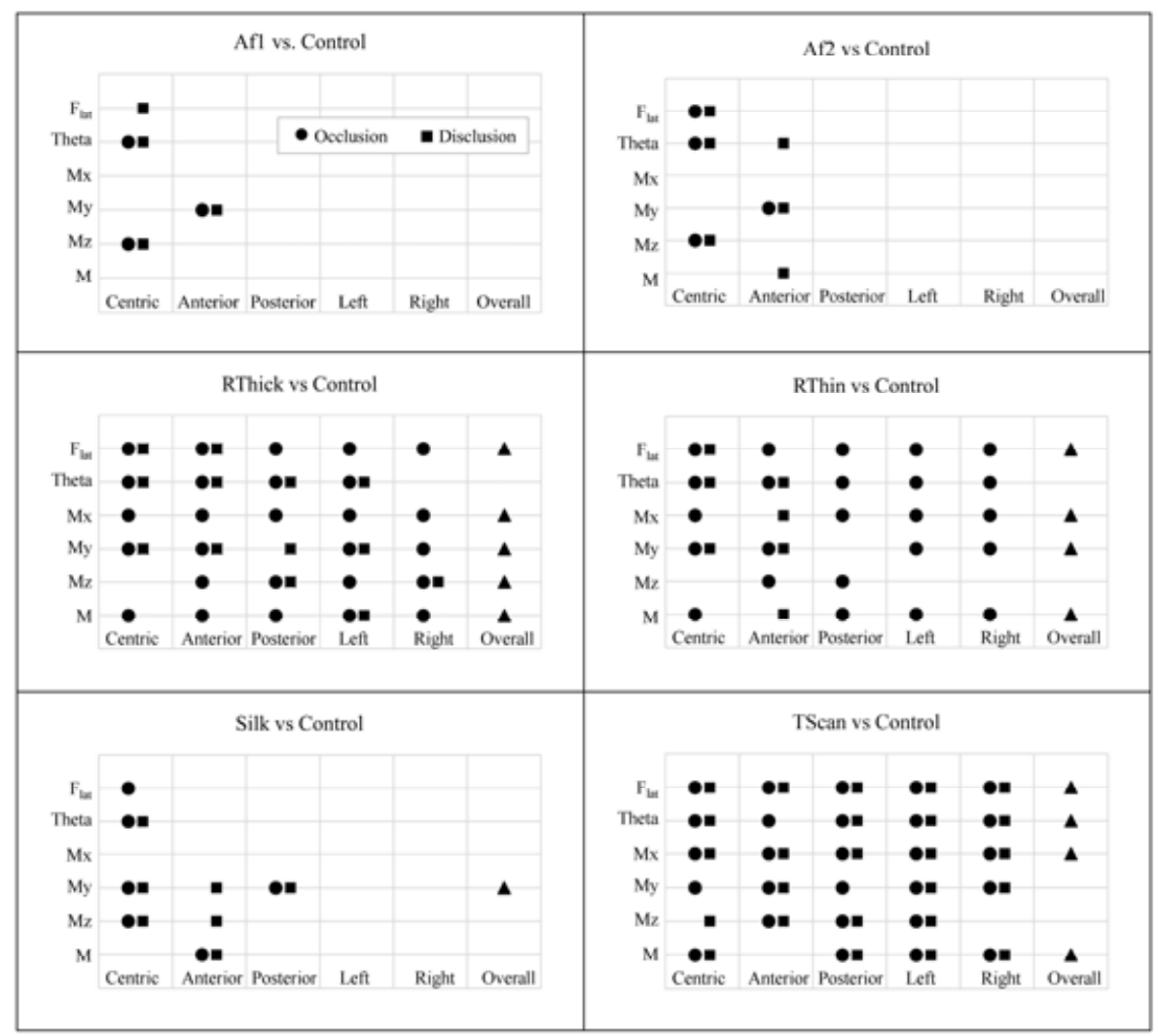

This article is protected by copyright. All rights reserved. 


\begin{tabular}{|c|c|c|c|c|c|c|c|c|c|c|c|}
\hline \multicolumn{6}{|c|}{ Afl: Occlusion vs. Disclusion } & \multicolumn{6}{|c|}{ Af2: Occlusion vs. Disclusion } \\
\hline \multirow{3}{*}{$\begin{array}{r}\mathbf{F}_{\text {lit }} \\
\text { Theta } \\
\text { Mx } \\
\text { My }\end{array}$} & • a & & & & & \multirow{6}{*}{$\begin{array}{r}\mathrm{F}_{\mathrm{im}} \\
\text { Theta } \\
\mathrm{Mx} \\
\mathrm{My} \\
\mathrm{Mz} \\
\mathrm{M}\end{array}$} & - & & & & \\
\hline & $\bullet$ & & Control & - Material & & & - & & & & \\
\hline & & & & & & & & & & & \\
\hline & & & & & & & & & & & \\
\hline \multirow{2}{*}{$\begin{array}{l}\mathrm{Mz} \\
\mathrm{M}\end{array}$} & $\bullet$ & & & - & & & $\bullet$ & & & $\bullet$ & - \\
\hline & Centric & Anterior & Posterior & Left & Right & & Centric & Anterior & Posterior & Left & Right \\
\hline \multicolumn{6}{|c|}{ RThick: Occlusion vs. Disclusion } & \multicolumn{6}{|c|}{ RThin: Ocelusion vs. Disclusion } \\
\hline \multirow{6}{*}{$\begin{array}{r}\mathrm{F}_{\mathrm{Lt} \text { }} \\
\text { Theta } \\
\mathrm{Mx} \\
\mathrm{My} \\
\mathrm{Mz} \\
\mathrm{M}\end{array}$} & - & - & . & घ & - & \multirow{6}{*}{$\begin{array}{r}F_{\mathrm{l}} \\
\text { Theta } \\
\mathrm{Mx} \\
\mathrm{My} \\
\mathrm{Mz} \\
\mathrm{M}\end{array}$} & \multirow[t]{3}{*}{ " } & & - & - & - \\
\hline & - & - & - & a & & & & & . & - & \\
\hline & - & - & - & - & & & & घ & घ & - & " \\
\hline & & - & 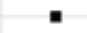 & घ & - & & & - & & - & - \\
\hline & & & - & & & & & - & - & & \\
\hline & Centric & $\underset{\text { Anterior }}{\|}$ & $\underset{\text { Posterior }}{=}$ & Left & Right & & Centric & Anterior & Posterior & Left & Right \\
\hline & & ilk: Occlu & tion vs. Di & clusion & & & & ican: Ocel & ision vs. D & clusion & \\
\hline $\mathbf{F}_{\text {lat }}$ & - & & & & & $\mathbf{F}_{\mathrm{lu}}$ & m & - & - & - & - \\
\hline Theta & - & & & & & Theta & $\bullet$ & . & . & . & - \\
\hline Mx & & & & & & Mx & " & = & & - & - \\
\hline My & & & & & & My & & & & . & . \\
\hline Mz & - & & & - & & $\mathrm{Mz}$ & - & - & & - & \\
\hline M & & & & & & M & & & & " & \\
\hline & Centric & Anterior & Posterior & Left & Right & & Centric & Anterior & Posterior & Left & Right \\
\hline
\end{tabular}

This article is protected by copyright. All rights reserved. 